\title{
EFEKTIVITAS ALAT PERAGA INDUKSI ELEKTROMAGNETIK TERHADAP KEMAMPUAN BERPIKIR KRITIS PESERTA DIDIK
}

\section{EFFECTIVENESS OF ELECTROMAGNETIC INDUCTION PROPS TO STUDENT'S CRITICAL THINKING ABILITY}

\author{
Isma Yunita ${ }^{1}$, Alinis Ilyas ${ }^{2}$ \\ ${ }^{1}$ Prodi Pendidikan Fisika Fakultas Tarbiyah dan Keguruan Universitas Islam Negeri Raden Intan Lampung \\ ${ }^{2}$ Prodi Pendidikan Agama Islam Fakultas Tarbiyah dan Keguruan Universitas Islam Negeri Raden Intan \\ Lampung
}

E-mail: ismayunita17@gmail.com

Diterima: 17 Juni 2019. Disetujui: 15 Juli 2019. Dipublikasikan: 31 Juli 2019

\begin{abstract}
The use of electromagnetic induction teaching aids is designed to create students who are active in the learning process so that they can improve their critical thinking skills. The ability to think critically is a reasonable and reflective thought that focuses on deciding what must be done. This study aims to determine the effectiveness of using teaching aids on students' critical thinking skills. The type of research conducted in this study was a quasy experiment with a non equivalent control group design. The population in this study was class XII MA Mathla'u Anwar Gisting. The sampling technique uses purposive sampling. With class XII IPA 1 as the experimental class and class XII IPA 2 as the control class. To measure the critical thinking skills of students, tests were carried out with 10 questions about essays and knowing the feasibility of using electromagnetic induction teaching aids can be done by observation. Furthermore, the data was tested using the normality, homogeneity, and T test. The results of the statistical tests showed a significant level $<0.05$, which means that $H O$ was rejected and $H 1$ was accepted. The results showed that there was effectiveness in using teaching aids on students' critical thinking skills in electromagnetic induction material.
\end{abstract}

Keywords: props, effectiveness, critical thinking skills

\begin{abstract}
Abstrak: Penggunaan alat peraga induksi elektromagnetik dirancang untuk menciptakan peserta didik yang aktif didalam proses pembelajaran sehingga dapat meningkatkan kemampuan berpikir kritis. Kemampuan berpikir kritis merupakan sebuah pemikiran yang masuk akal dan reflektif yang berfokus untuk memutuskan apa yang mesti dilakukan. Penelitian ini bertujuan untuk mengetahui efektivitas penggunaan alat peraga terhadap kemampuan berpikir kritis peserta didik. Jenis penelitian yang telah dilakukan dalam penelitian ini adalah quasy experiment dengan desain non equivalent control group. Populasi pada penelitian ini adalah kelas XII MA Mathla'u Anwar Gisting. Teknik pengambilan sampel menggunakan purposive sampling. Dengan kelas XII IPA 1 sebagai kelas eksperimen dan kelas XII IPA 2 sebagai kelas kontrol. Untuk mengukur kemampuan berpikir kritis peserta didik dilakukan tes dengan soal esay berjumlah 10 soal serta mengetahui keterlaksanaan dalam penggunaan alat peraga induksi elektromagnetik dapat dilakukan dengan observasi. Selanjutnya data di uji dengan menggunakan uji normalitas, homogenitas, dan uji T. Hasil uji statistik menunjukkan taraf signifikan $<0,05$ yang berarti $\mathrm{H}_{0}$ ditolak dan $\mathrm{H}_{1}$ diterima. Hasil penelitian menunjukkan bahwa terdapat keefektivitasan penggunaan alat peraga terhadap kemampuan berpikir kritis peserta didik pada materi induksi elektromagnetik.
\end{abstract}

(C) 2019 Unit Riset dan Publikasi Ilmiah FTK UIN Raden Intan Lampung

Kata Kunci: alat peraga, efektivitas, kemampuan berpikir kritis 


\section{PENDAHULUAN}

Pendidikan merupakan upaya setiap orang untuk meningkatkan dan mengembangkan kemampuan yang ada dalam dirinya selaras dengan nilai-nilai yang ada di dalam lingkungan dan kebudayaan. Fisika adalah ilmu pengetahuan dan teknologi yang mempelajari fakta, hukum, konsep, postulat serta teori yang harus dipahami, pemahaman yang terkait adalah fenomena alam, gejala, kejadian, serta interaksi dari benda-benda yang ada di alam sekitar (Jumiati, Febrianti, \& Hafika, 2016) Memiliki konsep yang tidak mudah dilihat secara langsung dan tidak mudah dihubungkan dengan keajdian sehari-hari pelajaran fisika masih terkesan sukar, dengan itu diharapkan untuk menciptakan media pembelajaran yang dapat membuat peserta didik menyukai pelajaran fisika (Tonaogy, Budi, \& Budi, 2014). Sehingga, dalam hal ini peserta didik mungkin memerlukan bantuan alat peraga yang dapat memberikan pengalaman langsung melaui demonstrasi ataupun praktikum serta untuk melihat sejauh mana kemampuan berpikir kritis peserta didik (Diani, Saregar, \& Ifana, 2016).

Berpikir kritis merupakan proses berpikir proses keharusan dalam usaha menyelesaikan masalah, menganalisis dan membuat keputusan (Tilaar, Jimmy, \& Paat, 2011). Berpikir kritis diterapkan kepada peserta didik untuk belajar memecahkan masalah secara sistematis, inovatif dan mencari solusi yang mendasar. Proses berpikir kritis juga merupakan proses kognitif, dalam pembelajaran dimulai dengan mengidentif ikasi permasalahan, menganalisa dan men gevaluasi.

Dengan adaya pengelolaan belajar yang baik akan mewujudkan suasana semangat belajar para peserta didik sehingga dapat meningkatkan hasil belajar (Djamarah \& Zain, 2010) Agar proses pembelajaran dapat berhasil dengan baik, peserta didik diajak untuk memanfaatkan semua panca inderanya. Pendidik mengupayakan untuk menampil kan rangasangan yang dapat diproses pada panca indera peserta didik. Semakin banyak panca indera yang digunakan untuk megolah informasi, maka kemungki nan besar informasi yang ditangkap dapat diingat dan dipahami.

Pemilihan media pembelajaran dalam proses pembelajaran sangat penting karena dapat menjadi salah satu faktor untuk keberhasilan dalam belajar. Alat peraga dapat digunakan untuk membantu pembelajaran yang menunujukkan fenomena atau konsep yang abstrak dan sulit dipahami, sehingga dapat menerangkan konsep, fakta, prinsip dan, prosedur tertentu agar tampak lebih jelas (Damayanti, Sutikno, \& Maturi, 2015). Alat peraga merupakan media pembelajaran yang dapat mempermudah peserta didik untuk mengamati dan memahami proses kejadiannya.

Alat peraga dapat menumbuhkan motivasi peserta didik untuk belajar pelajaran fisika, dengan alat peraga juga peserta didik dapat aktif dan berpikir kritis sehingga proses pembelajaran tidak membosankan dan monoton. Sehingga alat peraga sangat efektif dan efisien digunakan dalam proses pembelajaran fisika. Terkhususnya materi-materi yang sifatnya abstrak yang memerlukan bantuan alat peraga seperti materi induksi elektromagnetik.

Sebuah gaya magnet baik diantara kawat lurus atau kawat melingkar berarus listrik dihasilkan oleh aliran arus listrik hal ini dapat dipelajari oleh materi induksi elektromagnetik (Purwanto, Hendri, \& Susanti, 2016). Untuk menggambarkan induksi elektromagnetik ini memerlukan media yang dapat menjelaskan proses terjadi induksi elektromagnetik tersebut. Sehingga sangat diperlukan bantuan alat peraga pada materi ini.

Aktivitas peserta didik dalam proses pembelajaran masih kurang yakni hanya sedikit peserta didik yang menunjukkan 
keaktifan berpendapat dan bertanya. Pertanyaan yang diajukan peserta didik juga belum menunjukkan pertanyaanpertanyaan kritis yang berkaitan dengan materi yang sedang dipelajari. Pada saat pendidik mengajukan pertanyaan, hanya beberapa peserta didik saja yang mampu menjawab pertanyaan. Jawaban dari pertanyaan masih sebatas ingatan saja, belum terdapat peserta didik yang menunjukkan jawaban analisis dari pertanyaan pendidik. Pemberian kecakapa $\mathrm{n}$ dan pengetahuan kepada peserta didik yang merupakan proses pembelajaran yan g dilakukan oleh pendidik dengan mengg unakan metode-metode tertentu. Pemberian kemampuan dan pegetahuan kepada peserta didik yang adalah proses pembelajaran yang dilakukan oleh pendidik dengan menggunakan metode tertentu. Metode merupakan alat untuk mencapai tujuan. Penggunaan metode yang tepat diharapkan makin efektif pada pencapaian tujuan tersebut (Suryosubroto, 2009). Salah satu metode yang dapat digunakan yaitu metode eksperimen. Metode eksperimen dapat membantu peserta didik untuk memahami jalannya proses kerja suatu benda (Masriani \& Dhafir, 2014) yang disampaikan oleh pendidik yang bersifat abstrak dan proses berbagai percobaan yang dapat memotiva si peserta didik dengan berbagai percobaa $\mathrm{n}$ sehingga peserta didik dapat berpikir dan memahami materi induksi elektromag netik ini.

Melalui kegiatan eksperimen di laboratorium, di samping itu meningkatkan kemampuan berpikir kritis, peserta didik juga mampu mencapai tiga ranah secara bersama-sama yaitu tingkat kognitif, afektif dan psikomotorik (Putri \& Djamas, 2017). Selaras pada KI 4 pada silabus kurikulum 13 menyatakan bahwa mengolah, menalar, dan menyaji dalam ranah abstrak terpaut dengan pengembangan serta bisa menggunakan metode sesuai pedoman keilmuan yang dipelajarinya disekolah secara individual, sehingga dalam proses pembelajaran fisika di sekolah diperlukan adanya kegiatan eksperimen. Kegiatan eksperimen yang dilaksanakan dalam proses pembelajaran fisika di sekolah tentunya memerlukan media alat peraga (Roechaeni \& Raihanati, 2015).

\section{METODE PENELITIAN}

Penelitian ini merupakan penelitian $q u$ asy experiment (Sanjaya, 2015) dan desain yang digunakanyaitu non equi valent control group (Sugiyono, 2015)

\begin{tabular}{lll}
\hline Kelas Eksperimen & $\mathrm{O}_{1}$ & $\mathrm{X}_{1}$ \\
$\mathrm{O}_{2}$ & & \\
Kelas Kontrol & $\mathrm{O}_{1}$ & $\mathrm{X}_{0}$ \\
$\mathrm{O}_{2}$ & &
\end{tabular}

Penelitian ini menggunakan dua variabel yaitu penggunaan alat peraga sebagai variabel bebas dan kemampuan $b$ erpikir kritis sebagai variabel terikat. Penelitian ini dilaksanakan di MA Mathla'u Anwar Gisting dengan teknik pemilihan sampel menggunakan $p u$ rposive sampling (Arikuntoro, 2013).

Instrumen yang digunakan dalam penelitian ini adalah tes dan observasi. Pengembangan instrument tes untuk mengukur kemampuan berpikir kritis yang dimulai dengan membuat kisi-kisi soal tes. Tes kemampuan berpikir kritis ini dilakukan sebelum dan sesudah diberikannya perlakuan.

Prosedur penelitian yang telah dilaksanakan terdiri tiga tahap yaitu tahap persiapan, tahap pelaksanaa, dan tahap pengolahan data. Pada tahap persiapan diawali dengan studi pendahuluan, studi kurikulum dan literatur, menyusun instrumen RPP, soal pretest dan posttest utuk mengukur kemampuan berpikir kritis. Pada tahap pelaksanaan diawali dengan pemberian pretest, kemudian pemberian perlakuan dengan menggunaka $\mathrm{n}$ alat peraga induksi elektromagnetikseba nyak 2 pertemuan dan yang terakhir pelaksanaan posttest. Pada tahap pengolahan data dilakukan analisis data hasil pretes dan posttest 
peserta didik dan lembar keterlaksanaanpe mbelajaran.

Untuk mengetahui keefektivitasan penggunaan alat peraga terhadap kemamp uan berpikir kritis peserta didik pada mate ri induksi elektromagnetik. Maka analisis data statistik dengan ,melakukan pengujian terhadap nilai pretest dan posttest peserta didik. Uji yang dilaksanakan berupa uji normalitas, uji homogenitas, dan uji hipotesis (uji t).

a. Uji normalitas

Uji normalitas bertujuan untuk mengetahui sebaran distribusi data yang diperoleh. Uji normalitas yang digunakan dalam penelitian ini adalah dengan menggunakanuji liliefors dengan taraf sig nifikasi 0,05 nilai $\mathrm{L}_{\text {hitung }} 0,163<\mathrm{L}_{\text {tabel }} 0,17$ 3 sehingga berdistribusi normal.

b. Uji homogenitas

Uji homogenitas dilakukan untuk melihat apakah data-data nilai yang didapat dari kedua kelompok memiliki kesamaan varians atau tidak. Pada penelitian ini, uji homogenitas dilakukan dengan menggunakan uji cronbach alpha dengan taraf signifikasi 0,05 nilai diperoleh $F_{\text {hitung }} 1,03<\mathrm{F}_{\text {tabel }} 1,70$ sehingga $\mathrm{H}_{0}$ diterima.

\section{c. Uji hipotesis (uji t)}

Uji hipotesis yang digunakan adalah apabi la datanya berdistribusi normal, yaitu Ujit. Uji-t merupakan tes statistik yang memungkinkan kita membandingkan dua skor rata rata, untuk menentukan probabilitas (pelu ang) bahwa perbedaan antara dua skor rata rata merupakan perbedaan yang nyata (Setyosari, 2015). Hasil pengujian ini mengarahkan pada pengujian hipotesis (Diani, Yuberti, \& Syafitri, 2016) Adapun hipotesis penelitiannya adalah:

$\mathrm{H}_{0}=$ Tidak terdapat keefektivitasan penggunaan alat peraga terhadap kemampuan berpikir kritis peserta didik pada materi induksi elektromagnetik $\mathrm{H}_{1}=$ Terdapat keefektivitasan penggunaan alat peraga terhadap kemampuan berpikir kritis peserta didik pada materi induksi elektromagnetik

\section{HASIL DAN PEMBAHASAN}

Untuk mengetahui mengetahui keterlaksanaan dari penggunaan alat peraga terhadap berpikir kritis peserta didik dalam pembelajaran, maka dilakuk an observasi keterlaksanaan pembelajara n. Selama proses pembelajaran berlangsu ng yang dibantu oleh pendidik matapelaj aran fisika yang bertindak sebagai observer.

Tabel 1. Keterlaksanaan Pembelajaran

\begin{tabular}{cccc}
\hline No & Pertemuan & $\begin{array}{c}\text { Presentase } \\
\text { kelas } \\
\text { eksperimen }\end{array}$ & $\begin{array}{c}\text { Presentase } \\
\text { kelas } \\
\text { kontrol }\end{array}$ \\
\hline 1 & $\begin{array}{c}\text { Pertemuan } \\
\text { ke 1 }\end{array}$ & $89,2 \%$ & $89,2 \%$ \\
2 & $\begin{array}{c}\text { Pertemuan } \\
\text { ke 2 }\end{array}$ & $96,4 \%$ & $96,4 \%$ \\
3 & $\begin{array}{c}\text { Pertemuan } \\
\text { ke 3 }\end{array}$ & $98,2 \%$ & $98,2 \%$ \\
4 & $\begin{array}{c}\text { Pertemuan } \\
\text { ke 4 }\end{array}$ & $98,2 \%$ & $98,2 \%$ \\
\hline
\end{tabular}

Berdasarkan pada tabel diatas seluruh kegiatan pembelajaran menggunakan alat peraga induksi elektromagnetik dengan rata-rata $95,5 \%$.

Dari kegiatan pemberian perlakuan terhadap sampel berupa penggunaan alat peraga pembelajaran, peneliti mendapatk an data skor pretest dan posttes kemamp uan berpikir kritis

Tabel 2. Rekapitulasi Skor Rata-Rata Pretest Dan Posttest Kemampuan Berpikir Kritis

\begin{tabular}{ccc}
\hline Kelas & Pretest & Posttest \\
\hline Kelas eksperimen & 44,28 & 77,14 \\
Kelas kontrol & 40 & 67,8 \\
\hline
\end{tabular}

Berdasarkan tabel terlihat bahwa rata-rata skor pretest dan posttest kelas eksperimen lebih tinggi dibandingkan rata-rata skor pretest dan posttest kelas kontrol. Hal ini menunjukkan bahwa penggunaan alat peraga berpengaruh terhadap peningkatan kemampuan berpikir kritis peserta didik 
Peningkatan kemampuan berpikir kemampuan berpikir kritis berdasarkan kritis ini juga dianalisis dengan indikator kemampuan berpikir kritis mengelompokkan instrument tes

Tabel 3. Presentase Pretes Dan Posttest Kemampuan Berpikir Kritis Keas Eksperimen Dan Kontrol

\begin{tabular}{llllll}
\hline No & $\begin{array}{l}\text { Indikator kemampuan } \\
\text { berpikir kritis }\end{array}$ & \multicolumn{2}{l}{ Kelas eksperimen } & \multicolumn{2}{l}{ Kelas kontrol } \\
\hline \multirow{2}{*}{$\begin{array}{l}\text { Penjelasan sederhana } \\
2\end{array}$} & $\begin{array}{l}\text { Pretest } \\
76,9 \%\end{array}$ & $\begin{array}{l}\text { Posttest } \\
89,4 \%\end{array}$ & $\begin{array}{l}\text { Pretes } \\
75,4 \%\end{array}$ & $\begin{array}{l}\text { Posttest } \\
83,6 \%\end{array}$ \\
& $\begin{array}{l}\text { Membangun } \\
\text { kemampuan dasar }\end{array}$ & $66,8 \%$ & $87,9 \%$ & $69,2 \%$ & $81,7 \%$ \\
4 & Membuat kesimpulan & $67,7 \%$ & $83,9 \%$ & $70,6 \%$ & $78,8 \%$ \\
5 & $\begin{array}{l}\text { Membuat penjelasan } \\
\text { langsung }\end{array}$ & $71,6 \%$ & $89,9 \%$ & $73,5 \%$ & $82,6 \%$ \\
Membuat strategi dan & $73,0 \%$ & $87,0 \%$ & $75,9 \%$ & $81,7 \%$ \\
\hline
\end{tabular}

Berdasarkan tabel diatas bahwa adanya peningkatan kemampuan berpikir kritis peserta didik sebelum dan sesudah dilakukannya perlakuan pada kelas eksperimen dan kontrol. Pada tabel diatas rata-rata yang didapat sebelum dan setealah dilakukannya perlakuan meningkat secara baik sehingga disimpulkan bahwa terdapat peningkatan kemampuan berpikir kritis peserta didik dengan menggunakan alat peraga induksi elektromagnetik.

Tabel 4. Hasil Uji Normalitas dan homogenitas Postest Data

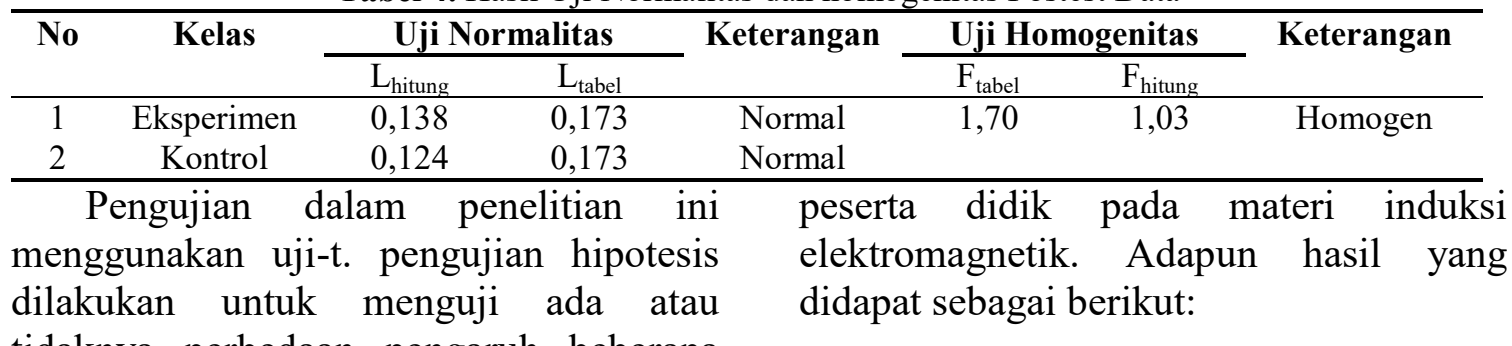
tidaknya perbedaan pengaruh beberapa perlakuan penggunaan alat peraga terhadap kemampuan berpikir kritis

Tabel 5. Rekapitulasi Hasil Perhitungan Uji Hipotesis Posttest Kelas Eksperimen Dan Kelas Kontrol

\begin{tabular}{ccccc}
\hline Kelompok & Jumlah Sampel & $\mathbf{T}_{\text {hitung }}$ & $\mathbf{T}_{\text {tabel }}$ & \multirow{2}{*}{ Keputusan Uji } \\
\cline { 3 - 4 } & & 0,05 & 0,05 & \\
\hline Eksperimen & 28 & 3,34 & 2,00 & $\mathrm{H}_{0}$ Ditolak \\
Kontrol & 28 & & & \\
\hline
\end{tabular}


Uji NGain bertujuan untuk mengetah ui besar peningkatan kemampuan berpikir kritis peserta didik pada kelas eksperimen dan kelas kontrol. Adapun hasil yang didapat sebagai berikut:

Tabel 6. Hasil Uji N-Gain Kelas Eksperimen Dan Kontrol

\begin{tabular}{ccc}
\hline & Kelas kontol & $\begin{array}{c}\text { Kelas } \\
\text { eksperimen }\end{array}$ \\
\hline N Gain & 0.22241 & 0.3965349 \\
Kategori & Rendah & Sedang \\
Tertinggi & 0.6 & 0.92307692 \\
Terendah & -1.2 & -1.2 \\
\hline
\end{tabular}

Uji effect size merupakan ukuran mengenai besarnya pengaruh suatu variabel pada variabel lain (Saregar, Latifah, \& Sari, 2016) Variabel yang sering terkait biasanya variabel independen dan variabel dependen. Untuk mengetahui efektivitas penggunaan alat peraga terhadap kemamp uan berpikir kritis peserta didik pada materi induksi elektromagnetik mengguna kan rumus effect size. Perolehan effect size dapat dilihat pada tabel:

\begin{tabular}{|c|c|c|c|c|}
\hline Kelas & Rata-rata gain & Standar deviasi & Effect size & Keterangan \\
\hline Eksperimen & 6,07 & 5,1 & 0,69 & Sedang \\
\hline Kon trol & 3,27 & 2,59 & & \\
\hline
\end{tabular}

Setelah dilakukan pengolahan data dan analisis data hasil penelitian maka dapat diketahui kemmapuan berpikir kritis peserta didik dapat dilihat dari nilai pretest dan posttest. Pretes diberikan diawal pertemuan sebelum diberikan perlakuan penggunaan alat peraga pada materi induksi elelktromagnetik.

Peningkatan hasil belajar pada kelas eksperimen lebih tinggi dibanding kelas kontrol Artinya, penggunaan alat peraga induksi elektromagnetik sebagai media pembelajaran mempunyai dampak positif terhadap hasil belajar siswa. Pemanfaatan alat peraga memiliki dampak positif dalam meningkatkan minat dan hasil belajar siswa yang ditandai dengan peningkatan hasil belajar tiap siklus. Pembelajaran menggunakan alat peraga memberikan hasil yang baik dan positif sebagai penunjang belajar peserta didik.

Peningkatan hasil belajar yang tinggi terletak pada jenjang kognitif C4 (menganalisis). Kemampuan menganalisis melibatkan proses memecah materi dan menentukan bagaimana hubungan antar bagian dan struktur keseluruhan. Sedangk an kemampuan mengevaluasi yaitu memb uat keputusan berdasarkan criteria dan standar tertentu. Kemampuan menganalisi $\mathrm{s}$ dan mengevaluasi dapat tercapai dengan bantuan alat peraga induksi elektromagnet ik. Hal ini dikarenakan pembelajaran men ggunakan alat peraga induksi elektromagn etik menuntut peserta didik untuk aktif dalam proses pembelajaran sehingga peserta didik mengalami pembelajaran secara langsung dari pengalamannya sendiri serta mengembangkan kemampua n berpikir (Diani, Julia, \& Rahayu, 2018). Hal ini menunjukkan bahwa demo ntrasi merupakan pengalaman belajar yang konkrit sehingga peserta didik akan mudah menganalisis dan mengevaluasi suatu hal yang berhubungan dengan materi induksi elektromagetik secara nyata. Selain itu, pengalaman dan kesan sebagai hasil pembelajaran menggunakan metode demonstrasi lebih melekat dalam diri peserta didik.

Selain dapat meningkatkan hasil belajar pada jenjang menganalisis (C4) dan mengevaluasi (C5), alat peraga induksi elektromagnetik juga mampu meningkatkan jenjang ko gnitif C6 (mencipta), hal ini dikarenakan mencipta (C6) melibatkan proses menyusun elemen -elemen menjadi sebuah keseluruhan yang fungsional sehingga dibutuhkan kreatifita s dan kemampuan awal peserta didik berdasarkan pengalaman belajarnya.

Berdasarkan analisis hasil tes pada kelas eksperimen dan kelas kontrol, kemampuan berpikir kritis peserta didik 
mengalami peningkatan pada setiap aspek aspek indikator kemampuan berpiki r kritis, aspek-aspek tersebut meliputi:

Aspek memberikan penjelasan sederh ana, Pada aspek memberikan penjelasan sederhana pada kelas kontrol secara kesuluruhan peserta didik sudah mampu menjawab teori suatu penjelasan atau tantangan dan memfokuskan pertanyaan. Aspek membangun kemampuan dasar, Pada aspek membangun kemampuan dasar, secara keseluruhan peserta didik sudah mampu mempertimbangkan kredibilitas suatu sumber. Aspek membuat kesimpulan, Pada aspek membuat kesimpulan dengan sub indikator membuat induksi dan mempertimbangkan hasil induksi. Secara keseluruhan peserta didik sudah mampu menentukan kesimpulan dari solusi permasalahan yang telah diperoleh namun masih banyak peserta didik yang dapat menarik kesimpulan namun belum dapat memberikan alternative-alternatif dalam penyelesaian masalah dalam soal.

Aspek membuat penjelasan lebih lanjut, Pada aspek membuat penjelasan lebih lanjut dengan sub indikator mengidentifikasi asumsi. Peserta didik sudah mampu memdefinisikan istilah dan mempertimbangkan suatu definisi dan mendefinisikan asumsi. Aspek membuat strategi dan taktik, Pada Aspek membuat strategi dan taktik dengan sub indikator menentukan suatu tindakan. Secara kesuluruhan peserta didik sudah mampu menentukkan solusi dari permasalahan dalam soal dan menuliskan jawaban.

Tahapan pembelajaran yang dilaksan akan dengan melakukan praktikumdengan ini peserta didik dengan mudah memahami materi induksi elektromagneti $\mathrm{k}$ yang bersifat abstrak dan tidak mudah dilihat secara langsung. Alat peraga induksi elektromagnetik ini dapat menjelaskan hukum-hukum yang ada di materi induksi elektromagnetik yaitu Huk um Faraday, Hukum Biotsavart, Hukum Lenz Dan Hukum Ampere, sehingga dengan menggunakan alat peraga ini peserta didik dapat mudah memahami induksi elektromagnetik.

Alat peraga induksi elektromagnetik i ni bertujuan untuk menjelaskan bagaiman a GGL dapat terinduksi oleh induksi elektromagnetik dan menyebutkan faktorfaktor yang mempengaruhinya serta mem ahami bahwa induksi elektromagnetik terj adi bila fluks magnetik berubah terhadap waktu. Melalui percobaan dengn menggunakan alat peraga induksi elektromagnetik ini kita dapat mengetahui pengaruh jumlah lilitan terhadap induksi. Jumlah lilitan dapat mempengaruhi besar GGL yang dihasilkan yakni semakin besar jumlah lilitan suatu kumparan maka GGL yang dihasilkan akan semakin besar pula, hal ini sesuai dengan Hukum Faraday, Dengan alat ini juga dapat membantu peserta didik mengetahui pengaruh diameter kumparan terhadap arus induksi artinya semakin besar diameter umparan maka arus yang dihasilkan akan semakin kecil. Pada alat peraga ini juga dapat membantu mengetahui pengaruh jarak kumparan ke magnet terhadap arus induksi, semakin jauh jaraknya kumparan pada medan magnet maka arus yang dihasilkan kecil dan bila jarak kumparan dekat dengan medan magnet maka arus yang dihasilakan besar, hal ini sesuai dengan Hukum Biotsavart, Dengan alat ini peserta didik juga dapat mengetahui kecepatan putar medan magnet terhadap arus induksi, dimana semakin cepat berputar seamkin besar juga tegangan induski yang dihasilkan dan semakin cepat pula perubahan garis gaya magnet yang masuk dalam kumparan sehingga menghasilkan pertambahan garis gaya yang dilingkupi kumparan sehingga timbul adanya garis gaya magnet yang baru yang berlawanan pertambahan gaya garis magnet (arah berputar kipas menyimpang kekanan atau kekiri) pada, hal ini sesuai dengan Hukum Lenz dan Alat peraga ini juga dapat menentukan 
Hukum Ampere yaitu medan magnet dapat ditimbulkan oleh dua cara yaitu melalui arus listrik dan dengan mengubah medan listrik. Pada rangkaian alat peraga induksi elektromagnetik ini menggunakan catu daya yang terhubung dengan stopkontak arus listrik dan apabila tidak ada catu daya atau listrik mati maka dapat memakai baterai ataupun medan magnet dapat diputar secara manual sehingga dapat mengubah medan listrik.

Melalui kegiatan praktikum kita dapat mengethaui faktor apa saja yang mempengaruhi besarnya GGL yaitu jumlah lilitan, besar kuat medan magnet, dan kecepatan gerak magnet. Dengan menggunakan alat peraga ini juga dapa merangkai alat peraga induksi elektromag etik serta meningkatkan kemampuan berpikir kritis peserta didik yang baik, alat peraga ini dapat digunakan untuk mengamati 4 percobaan yaitu 1) pengaruh jumlah lilitan terhadap arus induksi, 2) pengaruh diameter kumparan terhadap arus induksi, 3) merangkai alat peraga induksi elektromagnetik, 3) pengaruh jarak kumparan ke magnet terhadap arus induksi, dan 4) pengaruh kecepatan putar magnet arus induksi.

Melalui kegiatan praktikum dengan menggunakan alat peraga induksi elektromagnetik memiliki dampak positif bagi peserta didik, disamping itu meningkatkan kemampuan berpikir kritis, peserta didik juga mampu mencapai tiga ranah secara bersama-sam yaitu tingkat kognitif, afektif dan psikomotorik. Dengan adanya praktikum dan demonstrasi unyuk menjelaskan konsep fisika dapat meningkatkan minat peserta didik untuk mempelajari fisika. Sehingga alat peraga yang digunakan dapat efektif untuk meningkatkan kemampuan berpikir kritis peserta didik.

Dengan demikian hipotesis peneliti diterima, sehingga dapat disimpulkan bahwa terdapat keefektivitasan penggunaa $\mathrm{n}$ alat peraga induksi elektromagnetik terhadap kemampuan berpikir kritis peserta didik pada materi induksi elektromagnetik.

\section{KESIMPULAN}

Berdasarkan hasil analisis, pengolah an data dan pembahasan maka peneliti dapat menarik kesimpulan bahwa terdapat kefektivitasan penggunaan alat peraga ind uksi elektromagnetik terhadap peningkata n kemampuan berpikir kritis peserta didik pada materi induksi elektromagnetik. Den gan demikian penggunaan alat peraga ind uksi elektromagnetik sangat membantu dalam proses kegiatan belajar mengajar fisika agar peserta didik lebih aktif sehingga pembelajaran akan lebih efektif dan efisien.

\section{DAFTAR PUSTAKA}

Arikuntoro, S. (2013). Prosedur Penelitian Suatu Pendekatan Praktik. Jakarta: Rineka Cipta.

Damayanti, H., Sutikno, \& Maturi. (2015). Pembelajaran Hukum Pascal Menggunakan Miniatur Mesin Hidrolik Untuk Meningkatkan Kemampuan Berpikir Kritis Siswa. Jurnal Jurusan Pendidikan Fisika, 4.

Diani, R., Julia, O. N., \& Rahayu, M. (2018). Efektivitas Model RMS ( Reading, Mind Mapping, and Sharing) Terhadap Concept Mapping Skill Peserta Didik. Indonesian Journal of Science and Mathematics Education, 1(1), 41-48.

Diani, R., Saregar, A., \& Ifana, A. (2016). Perbandingan Model Pembelajaran Problem Based Learning dan Inkuiri Terbimbing Terhadap Kemampuan Berpikir Kritis Peserta Didik. Jurnal Penelitian Pembelajaran Fisika, 7(2), 147-155.

Diani, R., Yuberti, \& Syafitri, S. (2016). Uji Effect Size Model Pembelajaran Scramble Dengan Media Video Terhadap Hasil Belajar Fisika Peserta Didik Kelas X MAN 1 Pesisir Barat. Jurnal Ilmiah Pendidikan Fisika Al-BiRuNi, 5(2). 
Djamarah, S. B., \& Zain, A. (2010). Strategi Belajar Mengajar. Jakarta: Rineka Cipta.

Jumiati, Febrianti, Y., \& Hafika, R. G. (2016). Pembuatan Alat Praktikum Termoskop Guna Menjelaskan Radiasi Kalor Berbasis Teknologi Murah dan Sederhana. Jurnal Jurusan Pendidikan Fisika.

Masriani, \& Dhafir, F. (2014). Peningkatan Hasil Belajar Siswa Melalui Metode Eksperimen Pada Materi Perubahan Wujud Benda Dalam Mata Pelajaran IPA Kelas V SDN Lenju. Jurnal Kreatif Takuludo, 5 .

Purwanto, A. E., Hendri, M., \& Susanti, N. (2016). Studi Perbandingan Hasil Belajar Siswa Menggunakan Media Phet Simulations Dengan Alat Peraga Pada Pokok Bahasan Listrik Magnet di Kelas IX SMPN 12 Kabupaten Tebo. EduFisika, 1 .

Putri, S. D., \& Djamas, D. (2017). Pengembangan Perangkat Pembelajaran Fisika Berbasis Keterampilan Berpikir Kritis Dalam Problem-Based Learning. Al-BiRuni, 6.

Roechaeni, S., \& Raihanati, D. (2015). Pengembangan Alat Peraga Fisika SMA Materi Hukum Newton Dan Aplikasinya. Prosiding Seminar Nasional Fisika (E-Journal), IV.

Sanjaya, W. (2015). Penelitian Pendidikan Jenis, Metode dan Prosedur (3rd ed.). Jakarta: Prenadamedia Grup.

Saregar, A., Latifah, S., \& Sari, M. (2016). Efektivitas Model Pembelajaran CUPS : Dampak Terhadap Kemampuan Berpikir Tingkat Tinggi Peserta Didik Madrasah Aliyah Mathla'ul Anwar Gisting Lampung. Al-BiRuni, 5. https://doi.org/10.24042/jpifalbiruni. v5i2.123

Setyosari, P. (2015). Metode Penelitian Pendidikan dan Pengembangan (4th ed.). Jakarta: Prenadamedia Grup.

Sugiyono. (2015). Metode Penelitian Pendidikan Pendekatan Kuantitatif, Kualitatif, dan R\&D. Bandung: Alfabeta.

Suryosubroto, B. (2009). Proses Belajar Mengajar di Sekolah. Jakarta: Rineka Cipta.

Tilaar, H. A. ., Jimmy, \& Paat, L. (2011). Pedagogik Kritis. Jakarta: Rajawali Pers.

Tonaogy, F., Budi, A. S., \& Budi, E. (2014). Pengembangan Media Pembelajaran Pada Materi Hukum Archimedes Untuk Meningkatkan Kemampuan Analisis Siswa. 